\title{
JOURNAL OF THE AUSTRALIAN AND NeW ZEALAND
}

\section{ACADEMY OF MANAGEMENT Vol 7 No 12001}

\section{TABLE OF CONTENTS}

Training Performance Raters Through Error-based Experiential Learning Shelda Debowski

Quality Enhancement in Doctoral Education: Developing a More Public Process Ruth Neumann and James Guthrie.

Lessons From the Evolution of the Strategy Paradigm

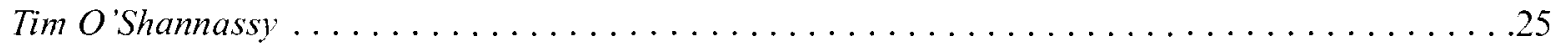

Australian Management Attitudes Toward Public Relations: Strategic Opportunities Lost

Carol J Steiner

Idealism, Gender and Business Decisions

Eva E Tsahuridu and Elizabeth Walker 